\title{
A microbial ecosystem beneath the West Antarctic ice sheet
}

\author{
Authors: Brent C. Christner, John C. Priscu, Amanda M. \\ Achberger, Carlo Barbante, Sasha P. Carter, Knut \\ Christianson, Alexander B. Michaud, Jill A. Mikucki, Andrew \\ C. Mitchell, Mark L. Skidmore, Trista J. Vick-Majors \& the \\ WISSARD Science Team.
}

NOTICE: this is the author's version of a work that was accepted for publication in Nature.

Changes resulting from the publishing process, such as peer review, editing, corrections, structural formatting, and other quality control mechanisms may not be reflected in this document. Changes may have been made to this work since it was submitted for publication. A definitive version was subsequently published in Nature, Issue \#512, August 2014, DOI\#10.1038/nature13667 http:// www.nature.com/nature/index.html

Christner, Brent C., John C. Priscu, Amanda M. Achberger, Carlo Barbante, Sasha P. Carter, Knut Christianson, Alexander B. Michaud et al. "A microbial ecosystem beneath the West Antarctic ice sheet." Nature 512, no. 7514 (2014): 310-313. http://dx.doi.org/10.1038/nature13667 


\section{A microbial ecosystem beneath the West Antarctic ice sheet}

Brent C. Christner, Amanda A. Achberger; Department of Biological Sciences, Louisiana State University, Baton Rouge, Louisiana 70803, USA

John C. Priscu, Alexander B. Michaud, Trista J. Vick-Majors; Department of Land Resources and Environmental Science, Montana State University, Bozeman, Montana 59717, USA

Carlo Barbante; Institute for the Dynamics of Environmental Processes - CNR, Venice, and Department of Environmental Sciences, Informatics and Statistics, Ca9Foscari University of Venice, Venice 30123, Italy

Sasha P. Carter; Institute of Geophysics and Planetary Physics, Scripps Institution of Oceanography, University of California San Diego, La Jolla, California 92093, USA.

Knut Christianson; Physics Department, St Olaf College, Northfield, Minnesota 55057, USA

Jill A. Mikucki; Department of Microbiology, University of Tennessee, Knoxville, Tennessee 37996, USA

Andrew C. Mitchell; Department of Geography and Earth Sciences, Aberystwyth University, Aberystwyth SY23 3DB, UK

Mark L. Skidmore; Department of Earth Science, Montana State University, Bozeman, Montana 59717, USA.

WISSARD Science Team

Liquid water has been known to occur beneath the Antarctic ice sheet for more than 40 years ${ }^{1}$, but only recently have these subglacial aque-ous environments been recognized as microbial ecosystems that may influence biogeochemical transformations on a global scale ${ }^{2-4}$. He re we present the first

geomicrobiological description of water and sur-ficial sediments obtained from direct sampling of a subglacial Ant-arctic lake. Subglacial Lake Whillans (SLW) lies beneath approximately $800 \mathrm{~m}$ of ice on the lower portion of the Whillans Ice Stream (WIS) in West Antarctica and is part of an extensive and evolving subglacial drainage network ${ }^{5}$. The water column of SLW contained metabol-ically active microorganisms and was derived primarily from glacial ice melt with solute sources from lithogenic weathering and a minor seawater component. Heterotrophic and autotrophic production data together with small subunit ribosomal RNA gene sequencing and biogeochemical data indicate that SLW is a chemosynthetically driven ecosystem inhabited by a diverse assemblage of bacteria and archaea. Our results confirm that aquatic environments beneath the Antarctic ice sheet support viable microbial ecosystems, corroborating previous reports suggesting that they contain globally relevant pools of carbon and microbes $^{2,4}$ that can mobilize elements from the lithosphere 6 and influence Southern Ocean geochemical and biological systems ${ }^{7}$

Almost 400 subglacial lakes have been identified beneath the Antarctic ice sheet ${ }^{8}$. Speculation on the presence of functional microbial ecosys-tems within these lakes followed their discovery ${ }^{1}$ and motivated the initial studies of samples originating from Subglacial Lake Vostok $(\mathrm{SLV})^{9,10}$. However, the body of microbiological data from SLV has been a point of contention, primarily because all studies were based on analyses of frozen (that is, accreted) lake water samples recovered from a borehole containing a contaminated hydrocarbon drilling fluid $^{3}$. Our report doc-uments the first analysis of water and surficial sediments collected directly from a subglacial lake beneath the West Antarctic ice sheet (WAIS) using microbiologically clean drilling and sampling techniques ${ }^{11}$.

The water residence time for SLV exceeds 10,000 years $^{12}$, while that for 'active' lakes such as SLW is on the order of years to decades ${ }^{5,8}$. SLW is part of a network of three major reservoirs beneath the lower ice plain of the WIS that regulate water transport to a subglacial estuary at the grounding zone, linking the hydrological system to the sub-ice-ocean cavity beneath the Ross Ice Shelf ${ }^{5,13}$ (Fig. 1). During two separate drainage events in 2006 and 2009, SLW discharged $\sim 0.15 \mathrm{~km}^{3}$ of water over two six-month periods, each time lowering the lake level by about $5 \mathrm{~m}^{5,14}$. T h e drilling location to access SLW was selected using reflection seismology ${ }^{13}$ and ice-penetrating radar $^{14}$ data, and corresponded to the region of maximum predicted water column thickness, lowest hydropotential, and largest satellite-measured surface elevation changes (Fig. 1).
A hot water drilling system was used to create a $\sim 0.6$ m diameter borehole through the overlying ice sheet into SLW, allowing for physical measurements and the direct collection of water column and sediment samples. Drilling and lake entry procedures followed recommendations for environmental protection of subglacial aquatic environments ${ }^{11}$, in c o $r$ - porating rigorous measures to reduce the introduction of foreign micro-biota and material into SLW and the interconnected subglacial drainage

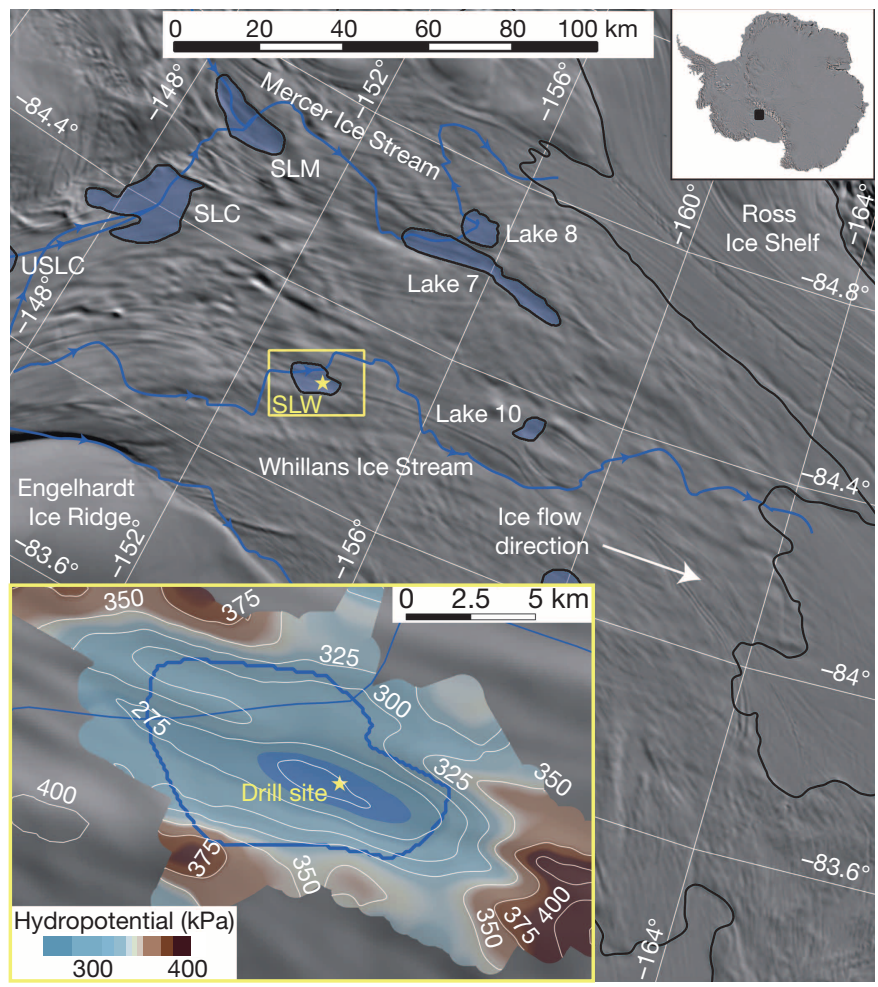

Figure $1 \mid$ Locator map of the WIS and SLW. The yellow box and star indicate the general location of the lake and the drill site; maximum extent of SLW and other lakes ${ }^{28}$ under the ice stream are shaded in blue; predicted subglacial water flowpaths through SLW and other subglacial lakes are represented by blue lines with arrows; the black line denotes the ice-sheet grounding line at the edge of the Ross Ice Shelf ${ }^{29}$. Inset (expanded from area in yellow box) shows details of SLW with both maximum (solid blue line) and minimum lake extent (shaded blue area), hydropotential contours (white isolines; $25 \mathrm{kPa}$ interval), and drill site (yellow star; $84.240^{\circ} \mathrm{S} 153.694^{\circ} \mathrm{W}$ ). Background imagery is MODIS MOA ${ }^{30}$. 
system. Video inspection of the borehole and temperature measurements revealed that the ice-water interface occurred at $801 \pm 1 \mathrm{~m}$ below the surface ( $\mathrm{mbs}$ ) and the lake depth at the borehole site was $\sim 2.2 \mathrm{~m}$ at the time of sampling. Two borehole deployments of a conductivity, temperature and depth (CTD) sonde together with data from three discrete hydrocasts showed that SLW had an average in situ temperature of $-0.49^{\circ} \mathrm{C}$, $\mathrm{pH}$ of 8.1 , and conductivity of $720 \mu \mathrm{S} \mathrm{m}^{-1}$; properties that were distinctly different from the borehole water (Table 1).

Water from three discrete hydrocasts in SLW had near identical geochemical compositions on the basis of major ion chemistry (Table 1) and all showed oxygen under-saturation $(\sim 16 \%$ of air-saturated water). Since there is no definitive evidence of lake water freezing to the bottom of the overlying ice sheet as in $\mathrm{SLV}^{12}$, it is unlikely that lake water con-stituents in SLW are influenced significantly by freeze concentration. The $\delta^{18} \mathrm{O}$ o f $\mathrm{H}_{2} \mathrm{O}$ for SLW $(-38.0 \%$ ) was similar to glacial ice sampled approximately $10 \mathrm{~m}$ above the ice-water interface from the neighbour-ing Kamb Ice Stream ${ }^{15}$ (KIS; -38 to $-39 \%$ ), indicating that glacial melt was the dominant water source for SLW. A considerable fraction of the major anions and cations originated

Table 1 | Biogeochemical data from the SLW borehole, water column, and surficial sediments

\begin{tabular}{|c|c|c|c|}
\hline Parameter & Borehole* & Water column $\dagger$ & Sediments: \\
\hline \multicolumn{4}{|l|}{ Physical } \\
\hline Temperature $\left({ }^{\circ} \mathrm{C}\right) \S$ & $-0.17(0.25)$ & $-0.49(0.03)$ & n.d. \\
\hline Conductivity $\left(\mu \mathrm{S} \mathrm{cm}^{-1} @\right.$ & 5.3 & $720(10)$ & 860 \\
\hline \multicolumn{4}{|l|}{$\left.25^{\circ} \mathrm{C}\right) \|$} \\
\hline $\mathrm{pH} \|$ & 5.4 & $8.1(0.1)$ & 7.3 \\
\hline Redox (mV (SHE)) $\|$ & n.d. & 382 & n.d. \\
\hline \multicolumn{4}{|l|}{ Microbiological } \\
\hline Cell density (cells ml ${ }^{-1}$ ) & $\begin{array}{c}6.9 \times 10^{2} \\
(51.0)\end{array}$ & $\begin{array}{r}1.3 \times 10^{5} \\
\left(0.4 \times 10^{5}\right)\end{array}$ & n.d. \\
\hline Cellular ATP (pmol I-1) & $0.04(0.002)$ & $3.70(1.00)$ & n.d. \\
\hline$\left.{ }^{[3} \mathrm{H}\right]$ thymidine & n.d. & $13.7(1.3)$ & $46.6(5.6)$ \\
\hline$\left.{ }^{[3} \mathrm{H}\right]$ leucine & n.d. & $2.9(0.4)$ & $0.9(0.04)$ \\
\hline${ }^{14} \mathrm{C}$-bicarbonate $\left(\mathrm{ng} \mathrm{Cl} \mathrm{l}^{-1} \mathrm{~d}^{-1}\right)$ & n.d. & $32.9(4.2)$ & n.d. \\
\hline \multicolumn{4}{|l|}{ Carbon and nutrients } \\
\hline Dissolved oxygen $\left(\mu \mathrm{mol}{ }^{-1}\right)$ & n.d. & $71.9(12.5)$ & n.d. \\
\hline $\mathrm{DIC}\left(\mathrm{mmol} \mathrm{I}^{-1}\right)$ & n.d. & $2.11(0.03)$ & n.d. \\
\hline $\mathrm{DOC}\left(\mu \mathrm{mol} \mathrm{I}^{-1}\right)$ & n.d. & $221(55)$ & n.d. \\
\hline Acetate $\left(\mu \mathrm{moll}{ }^{-1}\right)$ & n.d & $1.3(0.2)$ & n.d. \\
\hline Formate $\left(\mu \mathrm{moll}{ }^{-1}\right)$ & n.d & $1.2(0.3)$ & n.d. \\
\hline PC\# & n.d. & $78.5(7.4)$ & $384.2(37.0)$ \\
\hline PN\# & n.d. & $1.2(0.4)$ & $21.5(1.7)$ \\
\hline PC:PN (molar) & n.d. & $65.4(0.3)$ & $17.9(0.4)$ \\
\hline $\mathrm{NH}_{4}{ }^{+}\left(\mu \mathrm{moll}{ }^{-1}\right)$ & n.d. & $2.4(0.6)$ & n.d. \\
\hline $\mathrm{NO}_{2}^{-}\left(\mu \mathrm{moll}^{-1}\right)$ & n.d. & $0.1(0.1)$ & n.d. \\
\hline $\mathrm{NO}_{3}-\left(\mu \mathrm{moll}{ }^{-1}\right)$ & n.d. & $0.8(0.5)$ & 9.1 \\
\hline $\mathrm{PO}_{4}{ }^{3-}\left(\mu \mathrm{moll}{ }^{-1}\right)$ & n.d. & $3.1(0.7)$ & 7.3 \\
\hline DIN:SRP (molar) & n.d. & $1.1(0.4)$ & n.d. \\
\hline \multicolumn{4}{|l|}{ Major ions $\left(\mu \mathrm{eq} \mathrm{I}^{-1}\right)$} \\
\hline $\mathrm{Na}^{+}$ & n.d. & $5,276(18)$ & 6,977 \\
\hline $\mathrm{K}^{+}$ & n.d. & $186(4.2)$ & $293(1.0) \star$ \\
\hline $\mathrm{Mg}^{2+}$ & n.d. & $507(12)$ & $596(101) \star$ \\
\hline $\mathrm{Ca}^{2+}$ & n.d & 859 (29) & $860(104) \star$ \\
\hline $\mathrm{F}^{-}$ & n.d. & $31.5(0.4)$ & 34.0 \\
\hline $\mathrm{Cl}^{-}$ & n.d. & $3,537(3.4)$ & 4,943 \\
\hline $\mathrm{Br}^{-}$ & n.d. & $6(0.01)$ & $7(0.4) \star$ \\
\hline $\mathrm{SO}_{4}^{2-}$ & n.d. & $1,111(0.4)$ & 1,230 \\
\hline $\mathrm{HCO}_{3}{ }^{-}$ & n.d & $2,111(35)$ & $2,238 * *$ \\
\hline \multicolumn{4}{|l|}{ Stable isotopes $\dagger$} \\
\hline$\delta^{18} \mathrm{O}$ of $\mathrm{H}_{2} \mathrm{O}$ & n.d. & $-38.0 \%$ & $-37.5 \%$ \\
\hline$\Delta^{17} \mathrm{O}$ of $\mathrm{NO}_{3}^{-}$ & n.d. & -0.1 to $0.2 \%$ & n.d. \\
\hline
\end{tabular}

* Borehole water sampled by hydrocast at $672 \mathrm{mbs}$ before lake entry.

$\dagger$ Water column data represent averages ( \pm s.d.) from hydrocasts collected on 28 January 2013 (cast 1 ), 30 January (cast 2) and 31 January (cast 3) 2013, except for $\left[{ }^{3} \mathrm{H}\right]$ leucine incorporation, which is an average of cast 1 and 3 only.

t The sediment data correspond to measurements from the upper $2 \mathrm{~cm}$ of surficial sediments. $\S$ Average ( \pm s.d.) of in situ measurements made through the lake water column at $\sim 10 \mathrm{~cm}$ intervals with a SBE 19plusV2 SeaCAT Profiler CTD on 28 January and 30 January 2013.

$\|$ Based on measurements from discrete water samples brought to the surface.

- Macromolecular incorporation rates of tritium were converted to cellular carbon and presented along with bicarbonate incorporation as average $\mathrm{ng} \mathrm{Cl}^{-1} \mathrm{~d}^{-1}$ ( \pm s.d.) for water or average $\mathrm{ng} \mathrm{C} \mathrm{d}^{-1}$ gram $\mathrm{dry}$ weight ${ }^{-1}( \pm$ s.d. $)$ of sediment.

\#Average $\left( \pm\right.$ s.d.) $\mu$ mol $I^{-1}$ for water and average $\left( \pm\right.$ s.d.) $\mu$ mol $g$ dry weight sed ${ }^{-1}$ for surficial sediment. $\star$ Surficial sediment porewater major ions are the average ( \pm range) of two replicates.

** Calculated based on charge balance.

$\dagger$ Values are per thousand and reported relative to V-SMOW. The range of 2 measurements is given for $\Delta{ }^{17} \mathrm{O}$ of $\mathrm{NO}_{3}$

n.d., no data available. from mineral weathering, with a minor seawater component based on $\mathrm{Cl}^{-}$to $\mathrm{Br}^{-}$ratios (Extended Data Table 1). Crustally derived nonseawater solutes in SLW showed a dom-inance of weathering products from silicate minerals $\left(\mathrm{Na}^{+}+\mathrm{K}^{+}\right)$over carbonate minerals $\left(\mathrm{Mg}^{2+}+\right.$ $\left.\mathrm{Ca}^{2+}\right)$, similar to other sub ice-sheet sys-tems in Greenland and Antarctica $^{6,7}$ (Supplementary Discussion). The dominant nonseawater anions $\left(\mathrm{SO}_{4}{ }^{2-}\right.$ and $\left.\mathrm{HCO}_{3}{ }^{-}\right)$were probably products of sulphide oxidation, carbonation reactions, and carbonate

dissolution ${ }^{7}$. Sulphide oxidation and carbonation reactions have been demonstrated to be microbially driven in subglacial systems and linked to enhanced rates of mineral weathering ${ }^{16}$. Although clay minerals are a potential source of the relatively high $\mathrm{F}^{-}$concentrations in SLW (Table 1), subglacial volcanism in the upstream catchment supplying SLW ${ }^{17}$ may also contribute.

Ammonium accounted for $73 \%$ of the dissolved inorganic nitrogen pool within the water column of SLW (Table 1). Given that mineral sources of ammonium are minor, the majority of the ammonium is probably from microbial mineralization. Soluble reactive phosphorus levels were similar to the total inorganic nitrogen pool (dissolved $\mathrm{N}: \mathrm{P}$ molar ratio of 1.1), implying a biologically nitrogen-deficient environment, relative to phosphorus. Unfortunately, sample limitations precluded measure-ment of dissolved organic $\mathrm{N}$ and $\mathrm{P}$ concentrations to assess their nutri-tional contribution. In addition to its nutritional role, ammonium is also an energy source for chemolithoautotrophic ammonium-oxidizing bac-teria and archaea. Evidence for complete nitrification in the aerobic SLW water column was supported by $\Delta^{17} \mathrm{O}$ of $\mathrm{N} \mathrm{O}_{3}$ values $(-0.1 \%$ to $0.2 \%$ ) that indicated microbial processes rather than atmospheric input was the dominant source for nitrate in the lake ${ }^{18}$. Particulate organic $\mathrm{C}(\mathrm{PC})$ to $\mathrm{N}$ (PN) molar ratios in the water column exceeded that of actively growing bacteria by almost 15-fold, suggestive of elevated levels of nitrogenpoor detritus. Dissolved organic carbon (DOC) in the water column averaged $221 \pm 55 \mu \mathrm{moll}^{-1}$, which is about five times greater than average values for the deep ocean ${ }^{19}$ and similar to the maximum range estimate for $\operatorname{SLV}^{9,20}\left(86-160 \mu \mathrm{moll}^{-1}\right)$. Acetate and formate concentrations in the water column averaged 1.3 and $1.2 \mu \mathrm{moll}^{-1}$, respectively, indicating that at least a portion of the DOC pool was labile. The conductivity and microbiological data (Table 1 and Fig. 2a) showed that little mixing occurred between the borehole water and lake, supporting the hypothesis that DOC in the water column originated from SLW. The lack of winnowing in sediment cores from SLW, in concert with the fact that similar DOC concentrations were obtained as the overlying ice moved $\sim 4$ m during the course of our operations, provided evidence that water column DOC did not result from sediment disturbance during drilling operations. The DOC in SLW most likely originated from upward dif-fusion of DOC associated with ancient marine sediments $^{4}$ (SLW sediment surface area:depth ratio $\approx 30,000$ ), chemoautotrophic production, or from a combination of both sources.

The average cell density in the SLW water column was $1.3 \times 10^{5}$ cells $\mathrm{ml}^{-1}$ (Table 1); microscopy revealed the presence of numerous morphotypes, approximately $10 \%$ of which were filamentous (Fig. 3). Cellular ATP, a proxy for viable biomass, in SLW was $3.7 \mathrm{pmol} \mathrm{ATP}^{-1}$ (Table 1). Cell and ATP concentrations were 188- and 93-fold higher, respectively, than those observed in the borehole water before breakthrough to SLW. Carbon biomass estimates for SLW water based on the ATP data

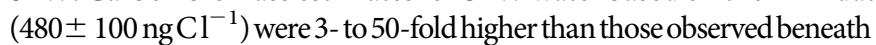
the Ross Ice Shelf at site J9 (ref. 21). Analysis of small subunit ribosomal RNA (SSU rRNA) sequences amplified from the water column samples showed that the community was similar among replicate lake samples, was distinct from the drilling water (Fig. 2a), and contained at least 3,931 operational taxonomic units (OTUs; Extended Data Table 2). An OTU closely related to the nitrite oxidizing betaproteobacterium 'Candidatus Nitrotoga arctica'22 comprised 13\% of the sequence data, and many of the most abundant phylotypes were closely related to chemolitho-autotrophic species that use reduced nitrogen, 


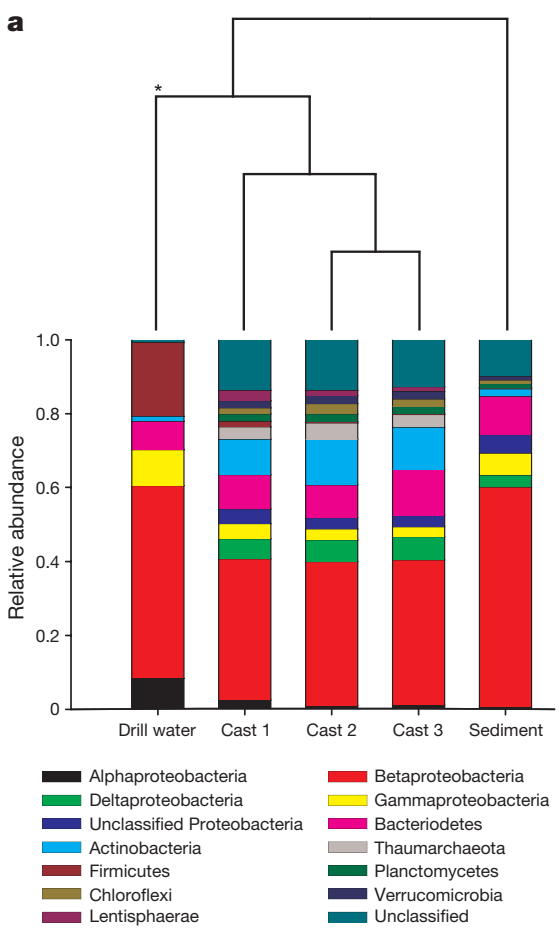

Figure $2 \mid$ Phylogenetic analysis of SSU gene sequences obtained from the SLW water column, surficial sediment $(0-2 \mathrm{~cm})$ and drilling water. a, Cluster analysis of the microbial phylogenetic structure in the samples (top) and the relative abundance of bacterial and archaeal phyla in the water and sediment samples (bottom). The Proteobacteria were split into classes for greater detail. The asterisk indicates statistical significance (analysis of molecular variance, AMOVA, $P$ value $<0.001$ ). b. Phylogenetic analysis of

iron or sulphur com-pounds as energy sources (Fig. 2b; Supplementary Discussion). Two of the abundant water column OTUs had high identity (>99\%) to SSU sequences previously reported from sediments sampled beneath the KIS ${ }^{23}$ (Fig. 2b). Preliminary attempts to detect eukaryotic SSU sequences in the SLW water column were unsuccessful.

Average dark $\left[{ }^{14} \mathrm{C}\right]$ bicarbonate incorporation in the water column samples (32.9 $\mathrm{ng} \mathrm{Cl}^{-1} \mathrm{~d}^{-1}$; Table 1) exceeded average rates of hetero-trophic production based on $\left[{ }^{3} \mathrm{H}\right]$ thymidine $\left(13.7 \mathrm{ng} \mathrm{Cl}^{-1} \mathrm{~d}^{-1}\right)$ and $\left[{ }^{3} \mathrm{H}\right]$ leucine $\left(2.9 \mathrm{ng} \mathrm{Cl}^{-1} \mathrm{~d}^{-1}\right)$ incorporation by 2 - and 11 -fold, respectively. Assuming that the thymidine and leucine values represent net incorpo-ration, and that respiratory losses were $87 \%$ of
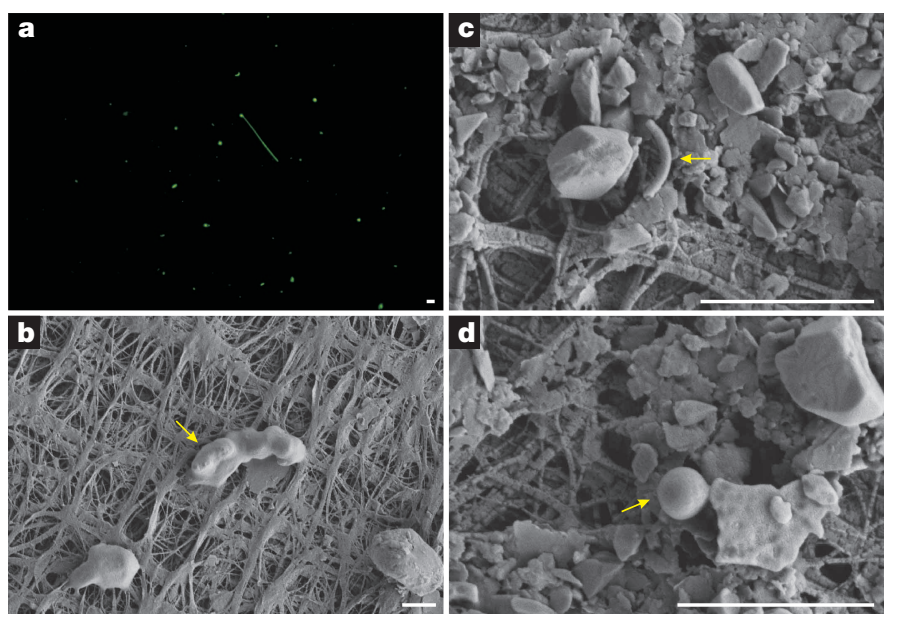

Figure 3 Morphological diversity of microbial cells in the SLW water column. a, Epifluorescence micrograph showing a variety of cell morphotypes, which was confirmed by scanning electron microscopy (SEM; b-d). The yellow arrows in the SEM images indicate cells with rod (b), curved rod (c) and coccoid (d) morphologies. Scale bar, $2 \mu \mathrm{m}$.

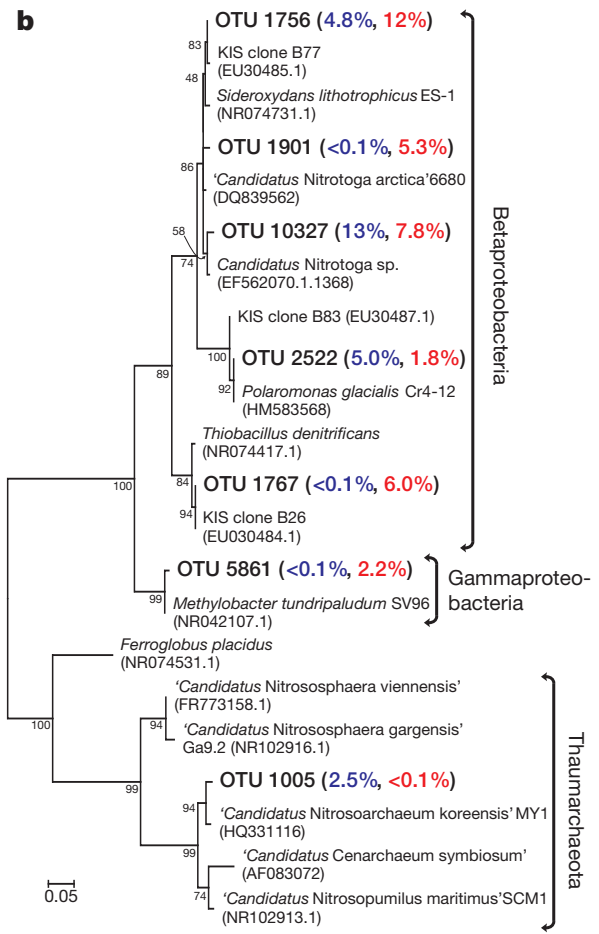

bacterial and archaeal OTUs abundant in the SLW water column and sediments. The accession numbers of nearest neighbours and reference taxa are listed parenthetically. Bootstrap values are shown at the nodes. SLW phylotypes are bolded and followed by the percentage each represented in the water column (blue) and sediment (red) libraries. The scale bar indicates the number of nucleotide substitutions per position.

net incorporation (which are average values for Antarctic McMurdo Dry Valley lakes ${ }^{24}$ ), the gross bacterial carbon demand (net productivity + respiration) would be 105 and $23 \mathrm{ng} \mathrm{Cl}^{-1} \mathrm{~d}^{-1}$, respectively. If dark $\left[{ }^{14} \mathrm{C}\right]$ bicarbonate incorp-oration represents new organic carbon production via chemoautotro-phy, the observed rates would meet between $31 \%$ and $143 \%$ of the heterotrophic carbon demand in the system. It should be noted that the effect of pressure ( $\sim 8 \mathrm{MPa}$ in SLW) was not tested and may influence the absolute rates of metabolism measured.

Pore water conductivity $\left(860 \mu \mathrm{Scm}^{-1}\right)$ and $\mathrm{pH}$ (7.3) in SLW's surfi-cial sediments were within $20 \%$ of the lake water values (Table 1 ). Upward diffusion of ions from sediment pore water is presumably the primary source of the ions in the water column. Average surficial sediment PC and PN concentrations were 384.2 and $21.5 \mu \mathrm{mol} g$ dry weight $^{-1}$, respec-tively, and represented $0.43 \%$ and $0.03 \%$ of sediment dry weight. The molar PC:PN ratio in the surficial sediment layer (17.9) was 3.7-fold lower than that in the water column (Table 1), indicative of nitrogen-enriched sedimentary particulate organic matter, with respect to water column suspensoids. On the basis of rates of thymidine and leucine incor-poration, average heterotrophic production in the surficial sediment was 46.6 and $0.9 \mathrm{ng} \mathrm{C} \mathrm{d}^{-1} \mathrm{~g} \mathrm{dry}$ weight $^{-1}$, respectively. Approximately $75 \%$ of the OTUs from the surficial sediments classified within the Proteo-bacteria (Fig. 2a). Although many phylotypes in the water column were also abundant in the surficial sediments (Fig. $2 \mathrm{~b}$ ), $\sim 70 \%$ of the OTUs were unique to the sediment environment. The nearest neighbours of the most abundant phylotypes in the surface sediments were chemolithoautotrophs or species that use $\mathrm{C} 1$ hydrocarbons as carbon and energy sources (Fig. 2b, Supplementary Discussion).

Our data show that SLW supports a metabolically active and phylogenetically diverse ecosystem that functions in the dark at sub-zero temperatures, confirming more than a decade of circumstantial evidence regarding the presence of life beneath Antarctica's ice sheet $^{9,10,20,23}$. Rate experiments revealed that chemoautotrophic primary 
production in SLW is adequate to support heterotrophic metabolism in the subglacial eco-system. The abundance of taxa related to nitrifiers ${ }^{22,25}$ in concert with elevated ammonium and $\Delta{ }^{17} \mathrm{O}$ o $\mathrm{f} \mathrm{N} \mathrm{O}_{3}$ values near $0 \%$ in the water column (Table 1 ) implies that nitrification may be a fundamental che-moautotrophic pathway of new organic carbon production in SLW. Similar conclusions regarding the ecological significance of nitrifica-tion have been drawn for the water column beneath the Ross Ice Shelf ${ }^{26}$ and in McMurdo Sound ${ }^{27}$. Given the prevalence of subglacial water in Antarctica ${ }^{8}$, our data from SLW lead us to contend that aquatic microbial ecosystems are common features of the subsurface environment that exists beneath the $\sim 10^{7} \mathrm{~km}^{2}$ Antarctic ice sheet.

Online Content Methods, along with any additional Extended Data display items and Source Data, are available in the online version of the paper; references unique to these sections appear only in the online paper

\section{Received 2 April; accepted 9 July 2014.}

1. Oswald, G. K. A. \& De Robin, G. Q. Lakes beneath the Antarctic ice sheet. Nature 245 251-254 (1973).

2. Priscu, J. C. et al. in Polar Lakes and Rivers (eds Vincent, W. \& Laybourn-Parry, J.) Ch.7 (Oxford Univ. Press, 2008).

3. Christner, B. C., Skidmore, M. L., Priscu, J. C., Tranter, M. \& Foreman, C. M. in (eds Margesin, R., Schinner, F., Marx., J.-C. \& Gerday, C.) Psychrophiles: From Biodiversity to Biotechology pp. 51-71 (Springer, 2008)

4. Wadham, J. L. et al. Potential methane reservoirs beneath Antarctica. Nature $\mathbf{4 8 8}$ 633-637 (2012).

5. Fricker, H. A., Scambos, T., Bindschadler, R. \& Padman, L. An active subglacial water system in West Antarctica mapped from space. Science 315, 1544-1548 (2007).

6. Skidmore, M., Tranter, M., Tulaczyk, S. \& Lanoil, B. Hydrochemistry of ice stream beds-evaporitic or microbial effects? Hydrol. Processes 24, 517-523 (2010).

7. Wadham, J. L. et al. Biogeochemical weathering under ice: size matters. Glob. Biogeochem. Cycles 24, GB3025 (2010).

8. Wright, A. \& Siegert, M. A fourth inventory of Antarctic subglacial lakes. Antarct. Sci. 24, 659-664 (2012).

9. Priscu, J. C. et al. Geomicrobiology of subglacial ice above Lake Vostok. Science 286, 2141-2144 (1999).

10. Karl, D. M. et al. Microorganisms in the accreted ice of Lake Vostok. Science $\mathbf{2 8 6}$ 2144-2147 (1999)

11. Priscu, J. C. et al. A microbiologically clean strategy for access to the Whillans Ice Stream subglacial environment. Antarct. Sci. 25, 637-647 (2013).

12. Bell, R. E. et al. Origin and fate of Lake Vostok water frozen to the base of the East Antarctic ice sheet. Nature 416, 307-310 (2002).

13. Horgan, H. J. et al. Estuaries beneath ice sheets. Geology 41, 1159-1162 (2013),

14. Christianson, K., Jacobel, R. W., Horgan, H. J., Anandakrishnan, S. \& Alley, R. B. Subglacial Lake Whillans-lce-penetrating radar and GPS observations of a shallow active reservoir beneath a West Antarctic ice stream. Earth Planet. Sci. Lett. 331-332, 237-245 (2012).

15. Vogel, S. W. et al. Subglacial conditions during and after stoppage of an Antarctic ice stream: is reactivation imminent? Geophys. Res. Lett. 32, L14502 (2005).

16. Montross, S. N., Skidmore, M., Tranter, M., Kivimäki, A.-L. \& Parkes, R. J. A microbia driver of chemical weathering in glaciated systems. Geology 41, 215-218 (2013).

17. Blankenship, D. D. et al. Active volcanism beneath the West Antarctic ice-sheet and implications for ice-sheet stability. Nature 361, 526-529 (1993).

18. Michalski, G., Bhattacharya, S. K. \& Girsch, G. NO $\mathrm{x}_{\mathrm{x}}$ cycle and tropospheric ozone isotope anomaly: an experimental investigation. Atmos. Chem. Phys. Discuss. 13, 9443-9483 (2013).

19. Hansell, D. A. \& Carlson, C. A. Deep-ocean gradients in the concentration of dissolved organic carbon. Nature 395, 263-266 (1998)

20. Christner, B. C. et al. Limnological conditions in Subglacial Lake Vostok, Antarctica. Limnol. Oceanogr. 51, 2485-2501 (2006).

21. Azam, F. et al. Occurrence and metabolic activity of organisms under the Ross Ice Shelf, Antarctica, at Station J9. Science 203, 451-453 (1979).

22. Alawi, M., Lipski, A., Sander, T., Pfeiffer, E.-M. \& Spieck, E. Cultivation of a novel coldadapted nitrite oxidizing betaproteobacterium from the Siberian Arctic. ISME J. 1, 256-264 (2007)

23. Lanoil, B. et al. Bacteria beneath the West Antarctic ice sheet. Environ. Microbiol. 11, 609-615 (2009).
24. Takacs, C., Priscu, J. \& McKnight, D. Bacterial dissolved organic carbon demand in McMurdo Dry Valley Lakes, Antarctica. Limnol. Oceanogr. 46, 1189-1 194 (2001).

25. Walker, C. B. et al. Nitrosopumilus maritimus genome reveals unique mechanisms for nitrification and autotrophy in globally distributed marine crenarchaea. Proc. Natl Acad. Sci. USA 107, 8818-8823 (2010).

26. Horrigan, S. G. Primary production under the Ross Ice Shelf, Antarctica. Limnol. Oceanogr. 26, 378-382 (1981).

27. Priscu, J. C., Downes, M. T., Priscu, L. R., Palmisano, A. C. \& Sullivan, C. W. Dynamics of ammonium oxidizer activity and nitrous oxide $\left(\mathrm{N}_{2} \mathrm{O}\right)$ within and beneath Antarctic sea ice. Mar. Ecol. Prog. Ser. 62, 37-46 (1990).

28. Fricker, H. A. \& Scambos, T. Connected subglacial lake drainage activity on lower Mercer and Whillans Ice Streams, West Antarctica, 2003-2008. J. Glaciol. 55, 303-315 (2009).

29. Depoorter, M. A. et al. Calving fluxes and basal melt rates of Antarctic ice shelves. Nature 502, 89-92 (2013).

30. Haran, T., Bohlander, J., Scambos, T. \& Fahnestock, M. MODIS mosaic of Antarctica (MOA) image map. http://dx.doi.org/10.7265/N5ZK5DM5 (National Snow and Ice Data Center, 2005).

Supplementary Information is available in the online version of the paper.

Acknowledgements The Whillans Ice Stream Subglacial Access Research Drilling (WISSARD) project was funded by National Science Foundation grants $(0838933$ 0838896, 0838941, 0839142, 0839059, 0838885, 0838855, 0838763, 0839107, $0838947,0838854,0838764$ and 1142123) from the Division of Polar Programs. Partial support was also provided by funds from NSF award 1023233 (B.C.C.), NSF award 1115245 (J.C.P.), the NSF's Graduate Research Fellowship Program (1247192; A.M.A.), the Italian National Antarctic Program (C.B.), and fellowships from the NSF's IGERT Program (0654336) and the Montana Space Grant Consortium (A.B.M.). Logistics were provided by the 139th Expeditionary Airlift Squadron of the New York Air National Guard, Kenn Borek Air, and by many dedicated individuals working as part of the Antarctic Support Contractor, managed by Lockheed-Martin. The drilling was directed by F. Rack; D. Blythe, J. Burnett, C. Carpenter, D. Duling (chief driller), D. Gibson, J. Lemery, A. Melby and G. Roberts provided drill support at SLW. L. Geng,

B. Vandenheuvel, A. Schauer and E. Steig provided assistance with the stable isotopic analyses. We thank J. Dore for assistance with the nutrient analysis.

Author Contributions The manuscript was written by B.C.C. and J.C.P.; A.M.A. generated and analysed the molecular data; C.B., A.C.M. and M.L.S. conducted and interpreted the chemical measurements; S.P.C. and K.C. provided geophysical data; J.A.M. obtained and examined the CTD data; A.B.M. and T.J.V. contributed and analysed physiological and biogeochemical data; M.L.S. conducted and interpreted the isotopic analyses; and T.J.V. provided the micrographs. All authors contributed to the study design and acquisition of samples and/or data.

Author Information The SSU sequence data are deposited in the NCBI SRA database under the accession number SRP041285. Reprints and permissions information is available at www.nature.com/reprints. The authors declare no competing financial interests. Readers are welcome to comment on the online version of the paper. Correspondence and requests for materials should be addressed to B.C.C. (xner@lsu.edu) or J.C.P. (jpriscu@montana.edu).

\section{WISSARD Science Team Members}

W. P. Adkins ${ }^{1}$, S. Anandakrishnan ${ }^{2}$, G. Barcheck ${ }^{3}$, L. Beem ${ }^{3}$, A. Behar ${ }^{4}$, M. Beitch ${ }^{3}$, R. Bolsey ${ }^{3}$, C. Branecky ${ }^{3}$, R. Edwards ${ }^{5}$, A. Fisher ${ }^{3}$, H. A. Fricker ${ }^{6}$, N. Foley $^{3}$, B. Guthrie ${ }^{7}$ T. Hodson ${ }^{7}$, R. Jacobel ${ }^{8}$, S. Kelley ${ }^{5}$, K. D. Mankoff ${ }^{3}$, E. McBryan ${ }^{4}$, R. Powell ${ }^{7}$, A. Purcell ${ }^{9}$ D. Sampson ${ }^{3}$, R. Scherer ${ }^{7}$, J. Sherve ${ }^{5}$, M. Siegfried ${ }^{6}$ \& S. Tulaczyk ${ }^{3}$

${ }^{1}$ Department of Biological Sciences, Louisiana State University, Baton Rouge, Louisiana 70803, USA. ${ }^{2}$ Department of Geosciences, Pennsylvania State University, University Park, Pennsylvania 16802, USA. ${ }^{3}$ Department of Earth and Planetary Sciences, University of California, Santa Cruz, Santa Cruz, California 95064, USA. ${ }^{4}$ School of Earth and Space Exploration, Arizona State University, Tempe, Arizona 85287, USA. ${ }^{5}$ Department of Land Resources and Environmental Science, Montana State University, Bozeman, Montana 59717, USA. ${ }^{6}$ Institute of Geophysics and Planetary Physics, Scripps Institution of Oceanography, University of California San Diego, La Jolla, California 92093, USA. ${ }^{7}$ Department of Geology and Environmental Geosciences, Northern Illinois University, DeKalb, Illinois 60115, USA. ${ }^{8}$ Physics Department, St Olaf College, Northfield, Minnesota 55057, USA. ${ }^{9}$ Department of Microbiology, University of Tennessee, Knoxville, Tennessee 37996, USA 


\section{METHODS}

Site selection and description. SLW was discovered using satellite laser altimetry and initially identified as a region $\left(59 \pm 12 \mathrm{~km}^{2}\right)$ of temporally varying surface elevation; it is one of 11 active subglacial lakes documented beneath the WIS ${ }^{5}$. SLW fills and drains every few years as part of a series of hydrologically linked subglacial lakes in the area, eventually draining to the ocean ${ }^{5,28,31}$. Ice-penetrating radar and active-source seismic data estimated that the maximum lake depth does not exceed 8 and $15 \mathrm{~m}$ at low- and high-stand, respectively ${ }^{14,32}$. A lake-level rise of $\sim 5 \mathrm{~m}$ from the low-stand lake level plus ice-flexural effects are sufficient to initiate flow over a drainage divide and trigger lake drainage. During a drainage event, $\sim 0.15 \mathrm{~km}^{3}$ of water drains in a six-month timeframe at a water flux of $\sim 10 \mathrm{~m}^{3} \mathrm{~s}^{-1}$ (refs 5, 14). Thus, SLW is a shallow active hydrological reservoir beneath an active ice stream. The deepest point in the seismically detected water column was selected as the drill site $\left(84.240^{\circ} \mathrm{S} 153.694^{\circ} \mathrm{W}\right.$; Fig. 1). Drilling and subglacial lake access occurred during a near low-stand state in late January $2013^{33}$.

Hot water drilling and clean access to SLW. A hot water drilling system was used between 23-27 January 2013 to melt through the $\sim 801 \mathrm{~m}$ thick ice sheet, creating an access borehole (minimum diameter $\sim 60 \mathrm{~cm}$ ) for direct sampling and to conduct in situ measurements of the SLW water column and sediments. Microbial cells in the drilling water and on exposed surfaces of the hose, cables, and deployed equipment were reduced and killed through the use of four complementary technologies: (1) filtration, (2) ultraviolet irradiation, (3) pasteurization, and (4) disinfection with $3 \% \mathrm{w} / \mathrm{v} \mathrm{H}_{2} \mathrm{O}_{2}$ (ref. 11). The drilling water, derived from the overlying ice sheet, was continuously circulated through a water treatment system that removed micron and sub-micron sized particles $(>0.2 \mu \mathrm{m})$, irradiated the drilling water with two germicidal wavelengths of ultraviolet radiation $\left(185 \mathrm{~nm} \sim 40,000 \mu \mathrm{W} \mathrm{s}{ }^{-1} \mathrm{~cm}^{-2}\right.$ and $254 \mathrm{~nm} \sim 175,000 \mu \mathrm{W} \mathrm{s}^{-1} \mathrm{~cm}^{-2}$ ), and pasteurized the water at $90{ }^{\circ} \mathrm{C}$ to reduce the viability of persisting microbial contamination. Ports were plumbed along the system's flow path, allowing discrete water samples to be obtained before and after each stage ${ }^{11}$. The drill hose and instrument cables were deployed at a rate no greater than $1 \mathrm{~m} \mathrm{~s}^{-1}$ through a custom borehole collar that contained 12 amalgam pellet ultraviolet lamps, providing a cumulative germicidal ultraviolet dosage of at least $40,000 \mu \mathrm{W} \mathrm{s}^{-1} \mathrm{~cm}^{-2}$ (Arapahoe SciTech). All borehole sampling tools and instruments were spray-saturated with $3 \% \mathrm{w} / \mathrm{v}_{2} \mathrm{O}_{2}$ and staged in sealed polyethylene bags until tool deployment. Single-use protective apparel (Tyvek) was worn by all personnel during borehole science operations. The efficacy of the clean access technology and procedures were tested thoroughly before use in the field and are detailed elsewhere $^{11}$.

Drilling was conducted at a flow rate of $\sim 135 \mathrm{l} \mathrm{min}^{-1}$ to $\sim 700 \mathrm{mbs}$, whereupon the drill was withdrawn, the borehole was inspected with video, and a hydrocast was conducted at $672 \mathrm{mbs}$ to measure the chemical and microbiological properties of the borehole water. To ensure that borehole water did not enter the lake upon breakthrough, the borehole hydrostatic pressure was reduced by $\sim 35 \%$ (that is, the water level was lowered from 80 to $108 \mathrm{mbs}$ ) below the expected equilibration level for $800 \mathrm{~m}$ of ice ${ }^{14}$. Drilling subsequently proceeded at the reduced flow rate of $191 \mathrm{~min}^{-1}$, and at 08:02 on 27 January (UTC+12), the load on the hose diminished as the drill reached $\sim 801 \mathrm{mbs}$. Two minutes later, the head above the borehole water return pump (stationed at $110 \mathrm{mbs}$ ) rose rapidly and remained at $\sim 80 \mathrm{mbs}$, confirming hydrostatic equilibration between the borehole and lake water (that is, breakthrough to SLW). Importantly, the rise in borehole water confirmed that no drilling water entered the subglacial environment during breakthrough. To maintain the borehole and offset freeze back, thermal energy was added to the borehole by redeploying the drill at a flow rate of $\sim 1351 \mathrm{~min}^{-1}$. Borehole reaming was conducted after breakthrough to the lake by slowly withdrawing the drill $\left(\sim 1 \mathrm{~m} \mathrm{~min}^{-1}\right)$. A second $24 \mathrm{~h}$ reaming occurred $32 \mathrm{~h}$ after initial penetration of the lake to ensure successful deployment of all sampling tools. All in situ measurements and discrete sampling occurred over a 3-day period.

Temperature and depth. A SBE 19plusV2 SeaCAT Profiler CTD (Seabird Electronics, Inc.) was used to measure temperature and depth within the borehole and lake water column. The instrument was deployed in profiling mode and lowered at a rate of $\sim 0.5 \mathrm{~m} \mathrm{~s}^{-1}$. Borehole depths are referenced to the snow surface in proximity to the borehole. The water column depth in SLW (that is, the distance between the ice-water interface and underlying sediments) was estimated using CTD data to distinguish differences in water mass upon entry to the lake water column from the borehole. Lake depth was obtained from the top of the lake water mass to the depth where the sonde contacted the bottom. This depth estimate was corroborated with a calibrated cable attached to a real-time borehole video camera.

Water and sediment sampling. Following ref. 11, discrete samples of the drilling water $(\sim 201)$ were obtained at two time points during the drilling process. Samples of water from the input to the filtration module, input to the borehole, water returning from the borehole, and a hydrocast at $672 \mathrm{mbs}$ before lake entry were collected and concentrated onto $142 \mathrm{~mm} 0.2 \mu \mathrm{m}$ Supor membrane filters (Pall Corporation).
The filters were processed identically to those from the SLW water column (see below).

Three discrete water samples were collected between 28 and 31 January 2013 at approximately mid-depth in the $\sim 2.2 \mathrm{~m} \mathrm{SLW}$ water column. Bulk water was collected using 101 Niskin bottles and transferred via acid $(10 \% \mathrm{HCl})$ leached silicon tubing to clean bottles following the limnological procedures outlined by the McMurdo Long Term Ecological Research (LTER) Program ${ }^{34}$.

SLW water column particulate matter for nucleic acid analysis was filter concentrated in situ using a Large Volume Water Transfer System (WTS-LV) that was modified to fit the minimum borehole diameter of $30 \mathrm{~cm}$ (McLane Research Laboratories Inc.). The WTS-LV has a 3-tier $142 \mathrm{~mm}$ filter holder that accepts filters in series for size fractionation of particulates in the sample water. There were three separate casts of the WTS-LV in SLW and between 4.9 and 7.21 of water was filterconcentrated during each $2 \mathrm{~h}$ deployment. In cast 1 , the filter housing was loaded with a $10 \mu \mathrm{m}$ nylon mesh screen together with $3 \mu \mathrm{m}$ and $0.2 \mu \mathrm{m}$ Supor membrane filters. The filters for cast 2 and 3 had pore sizes of $3.0 \mu \mathrm{m}, 0.8 \mu \mathrm{m}$, and $0.2 \mu \mathrm{m}$. Immediately after recovery, the filter housing unit was detached from the pump and opened in a class 100 laminar flow hood. The filters were placed in sterile $142 \mathrm{~mm}$ Petri dishes, sliced into quarters with a clean scalpel, and transferred to a cryovial that contained $7 \mathrm{ml}$ of DNA lysis solution (40 mM EDTA pH 8.0, $50 \mathrm{mM}$ Tris pH 8.3, $0.73 \mathrm{M}$ sucrose). The preserved samples were immediately frozen for transport to McMurdo Station and stored at $-80^{\circ} \mathrm{C}$.

Surficial sediments were collected using a multicoring device (Uwitec) that had a core barrel inner diameter of $59.5 \mathrm{~mm}$. Sediment pore water was obtained by inserting Rhizon samplers ${ }^{35}(0.2 \mu \mathrm{m}$ pore size $)$ through predrilled holes in the core barrel liner and extracted under negative pressure created with a $10 \mathrm{ml}$ sterile syringe. Surficial sediment ( 0 to $2 \mathrm{~cm}$ depth) from the cores was sampled inside a class 100 clean hood using a cleaned core cutter (Uwitec). The sediment samples for molecular biological analysis were placed in $60 \mathrm{ml}$ sterile Nalgene bottles containing $10 \mathrm{ml}$ of the DNA lysis solution and frozen.

Specific electrical conductivity (at $25^{\circ} \mathrm{C}$ ) and $\mathrm{pH}$ of the lake and sediment pore water were determined using a YSI model 3252 probe connected to a YSI model 3100 conductivity meter and a Beckman model $200 \mathrm{pH}$ meter. Both probe and meter combinations were calibrated immediately before sample measurements were made. Inorganic and organic chemistry. Particulate organic C (PC) and N (PN) samples from the water column were vacuum $(\sim 0.3 \mathrm{~atm})$ filtered onto pre-combusted $\left(450^{\circ} \mathrm{C}\right.$ for $\left.4 \mathrm{~h}\right)$ Whatman $\mathrm{GF} / \mathrm{F}$ filters and analysed on a CE Instruments Flash EA 112 (ThermoQuest, San Jose, CA). The filters and sediment samples which had been dewatered via centrifugation were fumed for $24 \mathrm{~h}$ over fresh $12 \mathrm{M} \mathrm{HCl}$ to remove inorganic carbon and dried for $24 \mathrm{~h}$ at $90^{\circ} \mathrm{C}$ before analysis. Dissolved oxygen was measured using the azide modification of the mini-Winkler titration ${ }^{36}$. Dissolved inorganic carbon was measured by infrared gas analysis of acid sparged samples. Samples for dissolved inorganic $\mathrm{N}$ and $\mathrm{P}$ were filtered through pre-combusted and $1 \% \mathrm{v} / \mathrm{v} \mathrm{HCl}$ leached GF/F filters, collected in $1 \% \mathrm{HCl}$ leached HDPE bottles, and frozen for shipment to the US where nitrate, nitrite, ammonium, and soluble reactive $\mathrm{P}$ were analysed colorimetrically ${ }^{34}$. Major ions and organic acids from SLW water and sediment porewater were analysed on a Metrohm ion chromatograph using a C4 cation column and an aSupp5 anion column.

Stable isotope analysis. Stable isotope measurements were conducted at the Isolab (University of Washington, Seattle). Measurements of oxygen isotope ratios of lake water and pore water samples were made using a Picarro cavity ring-down laser spectrometer. Nitrate for $\Delta^{17} \mathrm{O}$ determination in the water samples was concentrated using an anionic resin ${ }^{37}$ followed by the bacterial reduction and thermal decomposition method ${ }^{38,39} \cdot \Delta^{17} \mathrm{O}$ of $\mathrm{NO}_{3}$ was analysed with a Finnigan Delta Plus Advantage isotope ratio mass spectrometer. Isotope measurements are reported using standard $\delta$ notation in per thousand relative to Vienna Standard Mean Ocean Water (VSMOW).

pH and oxidation-reduction measurements. Sediment $\mathrm{pH}$ was measured with a Microelectrodes Inc. MI-407P needle $\mathrm{pH}$ electrode and a $\mathrm{MI} 401 \mathrm{Ag} / \mathrm{AgCl}_{2}$ micro reference electrode, calibrated with Orion low ionic strength buffers ( $\mathrm{pH} 4,7,10)$. Oxidation-reduction potential (ORP) was measured in SLW water with a glass epoxy platinum electrode and a MI $401 \mathrm{Ag} / \mathrm{AgCl}_{2}$ micro reference electrode calibrated with Zobell's solution and corrected to the standard hydrogen electrode (SHE). Cell and ATP concentration. Samples for cell enumeration from water and sediment were collected in combusted glass bottles and fixed in sodium borate-buffered formalin $(2 \% \mathrm{v} / \mathrm{v})$. Sub-samples were filtered on black $0.2 \mu \mathrm{m}$ polycarbonate membrane filters, stained with SYBR Gold (Life Technologies), and immediately counted via epifluorescence microscopy. Sediment interference did now allow accurate determination of cell density in sediment samples. Cellular ATP was measured in triplicate as previously described ${ }^{11}$ and viable biomass was estimated from the ATP concentration using a carbon to ATP ratio of 250 by weight ${ }^{10,21}$.

Scanning electron microscopy. Samples for scanning electron microscopy (SEM) were fixed with either $2 \%(\mathrm{w} / \mathrm{v})$ formalin or $0.5 \%(\mathrm{w} / \mathrm{v})$ glutaraldehyde and filtered 
onto a $13 \mathrm{~mm}$ diameter $0.2 \mu \mathrm{m}$ polytetrafluoroethylene (PTFE) filters. Following ethanol dehydration and critical point drying, the filters were attached to an aluminium stub, coated with either gold or palladium, and observed on a Zeiss Supra 55VP Field Emission Scanning Electron Microscope.

Heterotrophic and chemoautotrophic production. Heterotrophic productivity was measured using $\left[{ }^{3} \mathrm{H}\right]$ methyl-thymidine incorporation into $\mathrm{DNA}^{40}$ and $\left[{ }^{3} \mathrm{H}\right]$ leucine incorporation into protein ${ }^{41}$. Samples $(1.5 \mathrm{ml} ; 10$ and 5 live and 10 and 5 trichloroacetic acid (TCA)-killed controls for casts 1 and 3, respectively) were incubated with $20 \mathrm{nM}$ radiolabelled thymidine (specific activity $20 \mathrm{Ci} \mathrm{mmol}^{-1}$ ) or leucine (specific activity $84 \mathrm{Ci} \mathrm{mmol}^{-1}$ ) at $4{ }^{\circ} \mathrm{C}$ in the dark for $175 \mathrm{~h}$ (average). A separate time-course experiment (data not shown) revealed that incorporation was linear over this incubation period. Incubations were terminated by the addition of $100 \% \mathrm{w} / \mathrm{v}$ cold TCA ( $5 \%$ final). Following centrifugation, a series of washes with cold $5 \% \mathrm{w} / \mathrm{v}$ TCA and cold $80 \% \mathrm{v} / \mathrm{v}$ ethanol were performed. The final pellet was dried overnight at $\sim 25^{\circ} \mathrm{C}$. Radioactivity in the pellet was determined with a calibrated liquid scintillation counter following the addition of $1 \mathrm{ml}$ of Cytoscint ES (MP Biomedicals). The rates of thymidine and leucine incorporation (nM TdR $\mathrm{d}^{-1}$ or nM Leu d ${ }^{-1}$ ) obtained at the incubation temperature $\left(4^{\circ} \mathrm{C}\right)$ were converted to the in situ temperature of $-0.49^{\circ} \mathrm{C}$ using an energy of activation of $48,821 \mathrm{~J} \mathrm{~mol}^{-1}$ determined from temperature gradient experiments (data not shown). Rates of macromolecular synthesis were converted to carbon production using $2.0 \times 10^{18} \mathrm{cells} \mathrm{mol}^{-1}$ thymidine ${ }^{42}$ and $1.42 \times 10^{17} \mathrm{cells} \mathrm{mol}^{-1}$ leucine $\mathrm{e}^{43}$, in concert with a cellular carbon content of $11 \mathrm{fg} \mathrm{C} \mathrm{cell}^{-1}$ (ref 44 ). For the sediment assays, a slurry was created by adding $1 \mathrm{~g}$ wet weight of sediment to $10 \mathrm{ml}$ of $0.2 \mu \mathrm{m}$-filtered SLW water. The processing of the sediment slurries was identical to water samples except a total of three $80 \% \mathrm{v} / \mathrm{v}$ ethanol rinses were performed to enhance the removal of unincorporated substrate. After drying, $200 \mu \mathrm{l}$ of tissue solubilizer (ScintiGest; Fisher Chemical) was added to each vial. The metabolic rate data were normalized per gram dry weight of sediment.

Dark $\mathrm{CO}_{2}$ fixation was determined in sterile $40 \mathrm{ml}$ glass vials filled to the top with sample (leaving no headspace) and capped with PTFE lined caps ( 10 and 5 live and 10 and 5 TCA-killed for casts 1 and 3, respectively). The vials were amended with sterile $\left[{ }^{14} \mathrm{C}\right]$ bicarbonate (stock concentration $=0.1144 \mathrm{mCi} \mathrm{ml}^{-1}$ ) to a final experimental concentration of $1 \mu \mathrm{Ci} \mathrm{ml}^{-1}$ and incubated in the dark at $4{ }^{\circ} \mathrm{C}$ for $281 \mathrm{~h}$ (average). A separate time-course experiment (data not shown) revealed that incorporation was linear over this incubation period. Incubations were terminated by the addition of cold TCA ( $2.5 \% \mathrm{w} / \mathrm{v}$ final concentration) and filtering onto $0.2 \mu \mathrm{m}$ polycarbonate filters. The filters were placed in $20 \mathrm{ml}$ scintillation vials, acidified with $0.5 \mathrm{ml}$ of $3 \mathrm{~N} \mathrm{HCl}$, and dried at $60^{\circ} \mathrm{C}$ for $24 \mathrm{~h}$. Radioactivity on the filters was determined with a calibrated liquid scintillation counter following the addition of $10 \mathrm{ml}$ of Cytoscint ES (MP Biomedicals).

Molecular and phylogenetic analysis of SSU rRNA gene sequences. DNA was extracted from a portion of each filter ( $1 / 8$ of a $142 \mathrm{~mm}$ filter) using the Power Water DNA Isolation Kit and from sediments ( $\sim 0.5 \mathrm{~g}$ wet weight) with the Power Soil DNA isolation kit (MO BIO Laboratories, Inc.). The extraction procedures followed those recommended by the manufacturer.

The SSU rRNA gene was amplified using the oligonucleotide primers 515F and $806 \mathrm{R}$, as described previously ${ }^{45}$. Amplification reactions ( $50 \mu \mathrm{l}$ each) were performed using 5 units of AmpliTaq Gold DNA polymerase LD (Invitrogen), $1 \times$ PCR Gold Buffer (Invitrogen), $3.5 \mathrm{mM} \mathrm{MgCl}_{2}, 10 \mathrm{pmol}$ of each primer, $200 \mu \mathrm{M}$ dNTPs, and 0.1-3 ng of DNA template. After 9 min of heat activation at $94^{\circ} \mathrm{C}$ (AmpliTaq Gold DNA polymerase is a chemical hot-start enzyme), 35 cycles of PCR were performed using the following amplification conditions: denaturation at $94^{\circ} \mathrm{C}$ for $45 \mathrm{~s}$, anneal-ing for $90 \mathrm{~s}$ at $50^{\circ} \mathrm{C}$, and elongation at $72{ }^{\circ} \mathrm{C}$ for $90 \mathrm{~s}$, with a terminal elongation at $72^{\circ} \mathrm{C}$ for $10 \mathrm{~min}$. The optimum number of cycles for PCR was determined by suc-cessively lowering the cycle number so that false positive amplification was pre-vented while amplification was possible for the lowest biomass samples analysed. The concentration of the PCR products were determined using the Quant-iT Pico Green dsDNA Assay Kit (Invitrogen). The amplicons were pooled and cleaned with the MoBio UltraClean PCR Clean-Up Kit. Sequencing was performed using the Illumina MiSeq platform (Selah Genomics, Greenville, SC).

Paired end sequence reads were assembled and quality filtered using the Mothur ${ }^{46}$ phylogenetic analysis pipeline (v1.33.2). The sequences were aligned with the SILVA
Incremental Aligner ${ }^{47}$ (SINA v1.2.11; database release 115). The aligned reads were checked for chimaeras using the Uchime algorithm ${ }^{48}$, as implemented within Mothur, and chimaeric sequences were removed from the data. Sequences with $>97 \%$ SSU rRNA gene sequence similarity were clustered into an OTU and representative sequences for each OTU were chosen for classification using the SILVA database. Diversity and richness estimates were calculated in Mothur ${ }^{46}$. Singletons were excluded from further analyses, and for simplicity of presentation, phyla represented by $<1 \%$ of the sequence reads were grouped into the unclassified category (Fig. 2a). Com-munity comparisons using Yue and Clayton theta similarity coefficient analysis and Weighted Unifrac were also performed within Mothur. MEGA 5.2 software was used for phylogenetic analysis using maximum likelihood, the Jukes-Cantor nucleotide substitution model (1,000 iterations), and a 253 nucleotide alignment. Attempts to detect SSU sequences from eukaryotes were based on previously published methods $s^{50}$.

31. Carter, S. P. \& Fricker, H. A. The supply of subglacial meltwater to the grounding line of the Siple Coast, West Antarctica. Ann. Glaciol. 53, 267-290 (2012).

32. Horgan, H. J. et al. Subglacial Lake Whillans-Seismic observations of a shallow active reservoir beneath a West Antarctic ice stream. Earth Planet. Sci. Lett. 331332, 201-209 (2012)

33. Siegfried, M. R., Fricker, H. A., Roberts, M., Scambos, T. A. \& Tulaczyk, S. A decade of West Antarctic subglacial lake interactions from combined ICESat and CryoSat-2 altimetry. Geophys. Res. Lett. 2013GL058616, doi:10.1002/2013GL058616 (2014).

34. Priscu, J. C. LTER Limno Methods Manual - MCM_Limno_Methods_current.pdf. http://www.mcmlter.org/data/lakes/MCM Limno Methods current.pdf (2013).

35. Seeberg-Elverfeldt, J., Schlüter, M., Feseker, T. \& Kölling, M. Rhizon sampling of porewaters near the sediment-water interface of aquatic systems. Limnol. Oceanogr. Methods 3, 361-371 (2005).

36. American Public Health Association. Standard methods for the examination of water and waste water (American Public Health Society Press, 1995).

37. Costa, A. W. et al. Analysis of atmospheric inputs of nitrate to a temperate forest ecosystem from $\Delta^{17} \mathrm{O}$ isotope ratio measurements. Geophys. Res. Lett. 38, L15805 (2011).

38. Casciotti. K. L. Sigman, D. M., Galanter Hastings, M., Bohlke, J. K. \& Hilkert, A. Measurement of the oxygen isotopic composition of nitrate in seawater and freshwater using the denitrifier method. Anal. Chem. 74, 4905-4912 (2002)

39. Kaiser, J., Hastings, M. G., Houlton, B. Z., Rockmann, T. \& Sigman, D. M. Triple oxygen isotope analysis of nitrate using the denitrifier method and thermal decomposition of $\mathrm{N}_{2}$ O. Anal. Chem. 79, 599-607 (2007).

40. Fuhrman, J. \& Azam, F. Thymidine incorporation as a measure of heterotrophic bacterioplankton production in marine surface waters: evaluation and field results. Mar. Biol. 66, 109-120 (1982).

41. Kirchman, D., K'nees, E. \& Hodson, R. Leucine incorporation and its potential as a measure of protein synthesis by bacteria in natural aquatic systems. Appl. Environ. Microbiol. 49, 599-607 (1985).

42. Bell, R. T. Estimating production of heterotrophic bacterioplankton via incorporation of tritiated thymidine. In: Kemp, P. F., Sherr, B. F., Sherr, E. B. \& Cole, J. J. (eds) Handbook of Methods in Aquatic Ecology (Lewis, 1993).

43. Chin-Leo, G. \& Kirchman, D. Estimating bacterial production in marine waters from the simultaneous incorporation of thymidine and leucine. Appl. Environ. Microbiol. 54, 1934-1939 (1988).

44. Kepner, R. L., Wharton, R., Jr \& Suttle, C. A. Viruses in Antarctic Lakes. Limnol. Oceanogr. 43, 1754-1761 (1998).

45. Caporaso, J. G. et al. Ultra-high-throughput microbial community analysis on the Illumina HiSeq and MiSeq platforms. ISME J. 6, 1621-1624 (2012).

46. Schloss, P. D. et al. Introducing mothur: open-source, platform-independent, community-supported software for describing and comparing microbial communities. Appl. Environ. Microbiol. 75, 7537-7541 (2009).

47. Pruesse, E., Peplies, J. \& Glöckner, F. O. SINA: accurate high-throughput multiple sequence alignment of ribosomal RNA genes. Bioinformatics 28, 1823-1829 (2012).

48. Edgar, R. C., Haas, B. J., Clemente, J. C., Quince, C. \& Knight, R. UCHIME improves sensitivity and speed of chimera detection. Bioinformatics 27, 2194-2200 (2011).

49. Holland, H. D. The Chemistry of the Atmosphere and Oceans (Wiley, 1978).

50. Amaral-Zettler, L. A., McCliment, E. A., Ducklow, H. W. \& Huse, S. M. A method for studying protistan diversity using massively parallel sequencing of $\mathrm{V} 9$ hypervariable regions of small-subunit ribosomal RNA genes. PLOS ONE 4, e6372 (2009). 
Extended Data Table 1 | Crustal and seawater components to SLW waters

\begin{tabular}{lcccccccc}
\hline & \multicolumn{7}{c}{$\mu \mathrm{eq} \mathrm{L^{-1 }}$} \\
\cline { 2 - 8 } & $\mathrm{Na}^{+}$ & $\mathrm{K}^{+}$ & $\mathrm{Mg}^{2+}$ & $\mathrm{Ca}^{2+}$ & $\mathrm{F}^{-}$ & $\mathrm{Cl}^{-}$ & $\mathrm{SO}_{4}{ }^{2-}$ & $\mathrm{HCO}_{3}{ }^{-}$ \\
\hline $\begin{array}{l}\text { SLW } \\
\text { Average }\end{array}$ & 5276 & 186 & 507 & 859 & 31.5 & 3537 & 1111 & 2111 \\
$\begin{array}{l}\text { Sea water } \\
\text { component }\end{array}$ & 3038 & 66 & 691 & 132 & 0.4 & 3537 & 366 & 16 \\
$\begin{array}{l}\text { Non-seawater, } \\
\text { crustal } \\
\begin{array}{l}\text { weathering } \\
\text { component }\end{array}\end{array}$ & 2239 & 120 & $-183^{\S}$ & 726 & 31.1 & 0 & 745 & 2096 \\
\hline
\end{tabular}

* Average values for hydrocasts 1,2 and 3

$\dagger$ Calculated using $\mathrm{Cl}^{-}$concentrations and ratios of each species to $\mathrm{Cl}^{-}$in seawater in $\mu \mathrm{eq} \mathrm{I}^{-1} ; \mathrm{Na}^{+} 0.859, \mathrm{~K}^{+} 0.019, \mathrm{Mg}^{2+} 0.195, \mathrm{Ca}^{2+} 0.037, \mathrm{~F}^{-} 0.00013, \mathrm{SO}_{4}{ }^{2-} 0.103$, and $\mathrm{HCO}_{3}{ }^{-} 0.004\left(\mathrm{ref}^{-} 49\right)$. $\$$ Calculated by subtracting the seawater component from the average SLW solute concentration for each ion.

$\S$ Negative values indicate the potential for ion exchange of $\mathrm{Mg}^{2+}$ with other cations on clay minerals present in suspended sediments of SLW.

Extended Data Table 2 | Summary of parameters for the SLW SSU gene sequence data

\begin{tabular}{lcccccc}
\hline Site & $\begin{array}{c}\text { Number of } \\
\text { Sequences }\end{array}$ & $\begin{array}{c}\text { Number of } \\
\text { OTUs }^{\dagger}\end{array}$ & Coverage $*^{*}$ & $\begin{array}{l}\text { Inverse } \\
\text { Simpson } \\
\text { Diversity } \\
\text { Index }\end{array}$ & $\begin{array}{c}\text { Shannon } \\
\text { Diversity } \\
\text { Index }{ }^{\ddagger}\end{array}$ & $\begin{array}{c}\text { Chao } \\
\text { Richness } \\
\text { Estimator }\end{array}$ \\
\hline $\begin{array}{l}\text { Drill and borehole } \\
\text { water }\end{array}$ & 984,412 & 962 & $99.8 \%$ & 11.0 & 3.4 & 5,370 \\
$\begin{array}{l}\text { SLW water } \\
\text { column }\end{array}$ & $2,686,526$ & 3,931 & $99.5 \%$ & 35.3 & 4.9 & 41,603 \\
SLW sediments & 333,600 & 2,424 & $97.3 \%$ & 31.8 & 5.1 & 42,079 \\
\hline
\end{tabular}

* Sequences remaining after quality filtering, and removal of chimaeric sequences and singletons.

$\dagger$ OTUs that passed quality filtering, excluding singletons.

† Calculated using Mothur ${ }^{46}$ 
Extended Data Table 2 | Summary of parameters for the SLW SSU gene sequence data

\begin{tabular}{lcccccc}
\hline Site & $\begin{array}{c}\text { Number of } \\
\text { Sequences }\end{array}$ & $\begin{array}{c}\text { Number of } \\
\text { OTUs }{ }^{\dagger}\end{array}$ & Coverage ${ }^{*}$ & $\begin{array}{l}\text { Inverse } \\
\text { Simpson } \\
\text { Diversity } \\
\text { Index }{ }^{*}\end{array}$ & $\begin{array}{c}\text { Shannon } \\
\text { Diversity } \\
\text { Index }{ }^{\ddagger}\end{array}$ & $\begin{array}{c}\text { Chao } \\
\text { Richness } \\
\text { Estimator }\end{array}$ \\
\hline $\begin{array}{l}\text { Drill and borehole } \\
\text { water }\end{array}$ & 984,412 & 962 & $99.8 \%$ & 11.0 & 3.4 & 5,370 \\
$\begin{array}{l}\text { SLW water } \\
\text { column }\end{array}$ & $2,686,526$ & 3,931 & $99.5 \%$ & 35.3 & 4.9 & 41,603 \\
SLW sediments & 333,600 & 2,424 & $97.3 \%$ & 31.8 & 5.1 & 42,079 \\
\hline
\end{tabular}

* Sequences remaining after quality filtering, and removal of chimaeric sequences and singletons. $\dagger$ OTUs that passed quality filtering, excluding singletons.

\$Calculated using Mothur ${ }^{46}$. 